\title{
Pengaruh Pengetahuan Dasar Matematika Terhadap Hasil Belajar Matematika Siswa Kelas X SMA Negeri 1 Lawa
}

\author{
(The Influence Of Mathematical Basic Knowledge On Mathematics Learning Outcomes Of \\ Class X Students In SMA Negeri 1 Lawa)
}

\author{
Anisa $^{1}$, Kodirun ${ }^{2}$, Busnawir $^{2}$, Rahmat $^{3}$ \\ ${ }^{1}$ Alumnus Jurusan Pendidikan Matematika FKIP Universitas Halu Oleo ; Co-author:anisamath@gmail.com \\ ${ }^{2}$ Dosen Pendidikan Matematika FKIP dan PPS Universitas Halu Oleo \\ ${ }^{3}$ Dosen Pendidikan Matematika FKIP Universitas Halu Oleo
}

\begin{abstract}
Abstrak: Penelitian ini bertujuan untuk (1) mendeskripsikan pengetahuan dasar matematika dan hasil belajar matematika siswa kelas X SMA Negeri 1 Lawa \& (2) menganalisis pengaruh pengetahuan dasar matematika terhadap hasil belajar matematika siswa kelas X SMA Negeri 1 Lawa. Populasi penelitian ini adalah seluruh siswa kelas X SMA Negeri 1 Lawa semester genap tahun ajaran 2017/2018 yang berjumlah 223 siswa. Dari populasi yang ada diambil sampel sebanyak 30\% tiap kelas, yakni sebanyak 67 siswa dengan teknik proportional random sampling. Data pengetahuan dasar matematika dan hasil belajar matematika siswa diperoleh dari soal tes matematika. Teknik analisis data yang digunakan adalah analisis korelasi sederhana dan analisis regresi linear sederhana pada taraf signifikansi sebesar 5\%. Hasil analisis data penelitian ini menunjukkan bahwa berdasarkan analisis deskriptif diperoleh nilai rata-rata pengetahuan dasar matematika sebesar 69,85 (kategori cukup), nilai maksimum 95, dan nilai minimum 40 dengan standar deviasi 15,496, Sedangkan rata-rata hasil belajar matematika sebesar 71,72 (kriteria cukup), nilai maksimum 95, dan nilai minimum 45 dengan standar deviasi 13,832. Pengetahuan dasar matematika mempunyai pengaruh positif yang signifikan terhadap hasil belajar matematika siswa kelas X SMA Negeri 1 Lawa
\end{abstract}

Kata kunci: Hasil Belajar Matematika, Pengetahuan Dasar Matematika.

\begin{abstract}
This study aims to (1) describe the basic knowledge of mathematics and mathematics learning outcomes of class X students of SMAN 1 Lawa \& (2) analyze the effect of basic knowledge of mathematics on mathematics learning outcomes of class X students of SMAN 1 Lawa. The population in this study were all students of class X SMAN 1 Lawa even semester $2017 / 2018$ academic year, totaling 223 students. From the population, 30\% of each class is taken sample, namely as many as 67 students with a proportional random sampling technique. Data on basic knowledge of mathematics and mathematics learning outcomes is obtained from mathematical test questions. The data analysis technique used is simple correlation analysis and simple linear regression analysis in a significance level of $5 \%$. The results of data analysis of this study indicate that based on descriptive analysis the average value of mathematics basic knowledge is 69.85 (sufficient category), maximum value of 95, and a minimum value of 40 with a standard deviation of 15.496 . While the average mathematics learning outcomes amounted to 71.72 (sufficient criteria), maximum value 95 , and minimum value 45 with a standard deviation of 13.832. Basic knowledge of mathematics had a significant positive effect on the mathematics learning outcomes of class X students of SMAN 1 Lawa.
\end{abstract}

Keywords: learning outcomes of mathematics, basic knowledge of mathematics.

\section{PENDAHULUAN}

Kualitas pendidikan dari lembaga pendidikan jenjang tertentu dapat dilihat dari kualitas yang dihasilkannya. Salah satu indikator untuk menilai kualitas pendidikan adalah hasil belajar yang dicapai oleh siswa, rendahnya hasil belajar merupakan salah satu masalah yang sering

kita jumpai di setiap sekolah-sekolah baik itu dari tingkat dasar maupun sampai perguruan tinggi.

Permasalahan pendidikan selalu muncul bersamaan dengan meningkatnya kemampuan siswa, situasi lingkungan yang ada, serta berkembangnya ilmu 
pengetahuan dan teknologi. Kualitas pendidikan dari lembaga pendidikan jenjang tertentu dapat dilihat dari kualitas yang dihasilkannya. Salah satu indikator untuk menilai kualitas pendidikan adalah hasil belajar yang dicapai oleh siswa, rendahnya hasil belajar merupakan salah satu masalah yang sering kita jumpai di setiap sekolah-sekolah baik itu dari tingkat dasar maupun sampai perguruan tinggi.

Salah satu bagian penting dalam sistem pendidikan nasional adalah matematika yang dipelajari pada setiap jenis dan jenjang pendidikan formal. Matematika adalah salah satu ilmu pengetahuan yang memiliki peranan penting bagi pengembangan mutu sumber daya manusia. Cara berpikir matematika yang sistematis, melalui urutan-urutan yang teratur dan tertentu dapat melatih otak terbiasa untuk memecahkan masalah secara sistematis, sehingga bila diterapkan dalam kehidupan nyata, masalah dapat diselesaikan lebih mudah. Selain itu, sifat matematika yang deduktif, melatih seseorang untuk menarik kesimpulan dari sifat-sifat umum, bukan dari hal-hal yang bersifat khusus sehingga ini melatih siswa untuk menganalisis suatu masalah, kemudian menarik kesimpulan. Hal inilah yang menyebabkan matematika merupakan ilmu yang sangat penting yang harus dipelajari oleh setiap orang dalam rangka meningkatkan mutu sumber daya manusia.

Berdasarkan observasi awal yang dilakukan di SMA Negeri 1 Lawa, jumlah siswa kelas X sebanyak 223 orang yang tersebar dalam tujuh kelas paralel. Ratarata nilai ulangan harian pertama siswa kelas X MIA 1 , X MIA 2 , X MIA 3 , X MIA, $\mathrm{X} \mathrm{IS} \mathrm{S}_{1}, \mathrm{X} \mathrm{IS}_{2}$ dan $\mathrm{X} \mathrm{IS}_{3}$ semester ganjil $2017 / 2018$ secara berturut-turut adalah $65,42,60,03,57,54,65,13,50,35,60,13$ dan 50,17. Hal ini menunjukkan pencapaian hasil belajar ulangan harian siswa secara keseluruhan belum menunjukkan hasil yang memuaskan. Mengingat nilai KKM kelas $X$ mata pelajaran matematika di sekolah tersebut adalah 68. Guru mata pelajaran matematika kelas $\mathrm{X}$ di sekolah tersebut menyatakan bahwa masalah umum yang dihadapi siswanya adalah mereka cenderung kesulitan dan keliru ketika menjawab atau menyelesaikan soal-soal matematika yang sudah mereka pelajari sebelumnya, baik itu materi dasar yang sejak lama mereka pelajari, maupun materi yang belum lama di pelajari.

Tujuan utama pembelajaran matematika di sekolah dasar adalah untuk memperoleh kecakapan dasar berhitung, menumbuhkan dan mengembangkan kemampuan berpikir logis dan kritis dalam memecahkan masalah yang dihadapi dalam kehidupan sehari-hari, mengembangkan sikap rasionalitas dan membentuk landasan berhitung yang kuat untuk mempelajari pengetahuan lebih lanjut.

Pengetahuan dasar sangat membantu siswa dalam proses belajar sisawa. Menurut Slameto (2015: 2), belajar merupakan suatu proses usaha yang dilakukan seseorang untuk memperoleh perubahan tingkah laku secara keseluruhan sebagai hasil pengalaman sendiri dan interaksi dengan lingkungannya. Menurut Sardin (2005: 6), belajar adalah kegiatan yang dilakukan untuk menguasai pengetahuan, kebiasaan, kemampuan, keterampilan dan sikap melalui hubungan timbal balik antara proses belajar dengan lingkungannya.

Hudojo (2003: 9) mengungkapkan pembelajaran matematika siswa diarahkan kepada pemahaman konsep-konsep matematika yang akan mengantarkan individu untuk berpikir matematis.

Pengetahuan dasar matematika ini merupakan pengetahuan matematika yang mendasar yang dipelajari sebelum mempelajari materi matematika lain. Menurut Slameto yang di kutip oleh Sardin (2008: 34) pengetahuan dasar siswa dalam mata pelajaran matematika di SMA merupakan akumulasi daya serap Pengaruh Pengetahuan Dasar Matematika Terhadap Hasil Belajar Matematika Siswa Kelas X SMA Negeri 1 Lawa (Anisa, Kodirun, Busnawir, Rahmat) 
siswa terhadap matematika sejak siswa tersebut mendapat pelajaran matematika mulai dari sekolah dasar sampai sekarang yang sifatnya sangat mendasar seperti penjumlahan, pengurangan, perkalian, pembagian, aplikasinya, perhitungan luas bangun datar, volume dan aplikasinya.

Hasil belajar menurut Maonde dkk (2016: 43-61), hasil belajar matematika dipengaruhi oleh banyak faktor, baik yang bersumber dari dalam diri siswa (internal) maupun yang berasal dari luar diri siswa (eksternal). Berdasarkan pendapat para ahli di atas, ada keterkaitan antara pengetahuan dasar dengan hasil belajar siswa. Oleh karena itu, matematika sebagai ilmu yang tersistematis perlu memperhatikan kemampuan pengetahun dasar matematika siswa. Menurut Russefendi (2003: 25), belajar matematika bagi seorang siswa merupakan proses kontinu sehingga diperlukan pengertian atau pengetahuan dasar matematika yang lebih baik pada permulaan untuk belajar selanjutnya.

Pengetahuan dasar dalam belajar matematika memberi pengaruh terhadap hasil belajar melalui berbagai proses: (1) dalam proses pembelajaran, pengetahuan dasar berfungsi sebagai "category label" yang mempengaruhi cara informasi baru diatur dan ditambahkan ke struktur pengetahuan yang sudah ada (the restructuring approach); (2) pengetahuan dasar berfungsi sebagai konteks asimilatif dimana materi baru dikaitkan dengan yang telah ada dan akibatnya pengetahuan meningkat dan lebih muda ditemukan melalui elaborasi (the elaboration approach); (3) aktivasi pengetahuan dasar meningkatkan akses ke pengetahuan tersebut selama proses pembelajaran (the accessibility approach); (4) pengetahaun dasar mempengaruhi belajar melalui kesiapan yang telah ada sehingga informasi yang relevan dapat diterima dengan lebih siap (the selective attention approach); (5) pengetahuan dasar mempengaruhi belajar melalui isyarat: semakin banyak pengetahuan dasar, semakin banyak pengetahuan yang tersedia dalam memori seseorang (the availability approach); (6) pengaktifan pengetahuan dasar ketika mempelajari materi baru dapat meningkatkan daya ingat dan pengambilan informasi dari pengetahuan yang sudah ada (the retrieval approach); (7) pengetahaun dasar disusun melalui schemata, yang mempengaruhi interpretasi dan pemahaman tentang situasi baru (the schema-transfer approach) dan yang terakhir; (8) pengetahuan dasar yang lebih, berakibat pada pengolahan informasi yang lebih cepat (representation-saving approach). Selain itu, menurut teorema pengaitan pengetahuan dasar dalam matematika antara satu konsep dengan konsep lainnya terdapat hubungan yang erat, bukan saja dari segi isi, namun juga dari segi rumusrumus yang digunakan.

Rendahnya pengetahuan dasar matematika siswa menjadi momok bagi semua sekolah yang ada di indonesia. Salah satunya adalah SMA Negeri1 Lawa. Hal in tentu berpengaruh pada hasil belajar siswa di SMA tersebut. Hal ini disebabkan siswa tidak atau kurang menguasai materimateri dasar matematika yang seharusnya telah dituntaskan di jenjang sebelumnya. Penguasaan yang kurang pada materi dasar matematika tersebut berakibat pada kesulitan siswa dalam memahami materi matematika berikutnya dan akan berdampak pada rendahnya hasil belajar matematika.

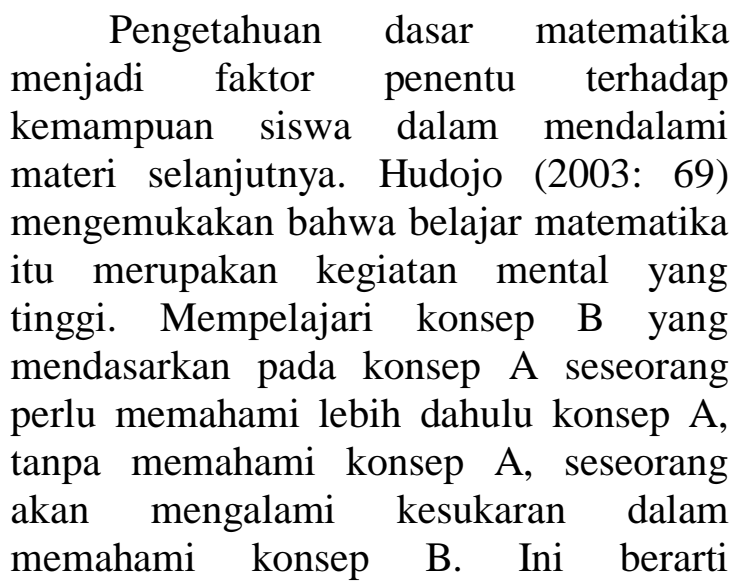


mempelajari matematika harus bertahap dan berurutan dan mendasar kepada

\section{METODE PENELITIAN}

Jenis penelitian yang digunakan adalah ex post facto. Metode ex post facto yaitu metode penemuan empiris yang dilakukan secara sistematis, peneliti tidak melakukan kontrol terhadap variabelvariabel bebas karena manifestasinya sudah terjadi atau variabel-variabel tersebut secara inheren tidak dapat dimanipulasi. Pada penelitian ini keterikatan antara variabel bebas dan variabel bebas, ataupun antara variabel bebas dan variabel terikat sudah terjadi secara alami. Dengan setting tersebut, pengalaman yang lalu.

peneliti ingin melacak kembali apa yang menjadi faktor penyebabnya.

Penelitian ini dilaksanakan pada semester genap tahun ajaran 2017/2018 di kelas X SMA Negeri 1 Lawa. Populasi dalam penelitian ini adalah seluruh siswa kelas X SMA Negeri 1 Lawa, yang berjumlah 223. Teknik yang digunakan dalam penentuan sampel adalah proportional random sampling yaitu masing-masing kelas di ambil 30\%. Berikut adalah tabel sebaran populasi dan sampel dalam penelitian ini.

Tabel 1. Sebaran Populasi dan Sampel Penelitian

\begin{tabular}{clll}
\hline No & Kelas & Jumlah siswa & Sampel (30\%) \\
\hline 1 & X MIA 1 & 32 & 10 \\
2 & X MIA 2 & 34 & 10 \\
3 & X MIA 3 & 32 & 10 \\
4 & X MIA 4 & 33 & 10 \\
5 & X IS 1 & 31 & 9 \\
6 & X IS 1 & 30 & 9 \\
7 & X IS 1 & 31 & 9 \\
& Jumlah & 223 & 67 \\
\hline
\end{tabular}

Variabel dalam penelitian ini terdiri dari satu variabel bebas yakni pengetahuan dasar matematika $(\mathrm{X})$, dan satu variabel terikat yakni hasil belajar matematika (Y). Desain dalam penelitian ini adalah sebagai berikut.

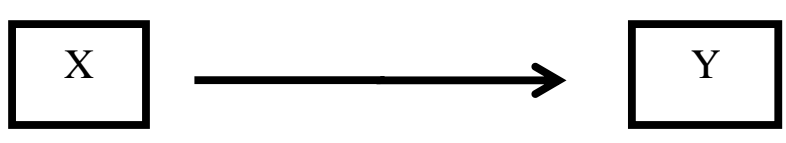

\section{Gambar 1. Desain Penelitian}

Keterangan :

$\mathrm{X}=$ Pengetahuan dasar matematika

$\mathrm{Y} \quad=$ Hasil belajar matematika siswa

Instrumen penelitian yang digunakan dalam penelitian ini adalah tes pengetahun dasar matemartika dan tes hasil belajar matematika siswa. Instrumen penelitian yang digunakan terlebih dahulu dilakukan uji validitas dan reliablitas. Untuk uji validitas, rumus yang digunakan adalah rumus Aiken yaitu sebagai berikut:

$$
V_{i}=\frac{\sum n_{i}\left|i-i_{0}\right|}{N(c-1)}
$$


Keterangan :

$V_{i} \quad$ : validitas isi

$n_{i} \quad$ : jumlah panelis yang memilih $\mathrm{i}$

I : skor pilihan setiap butir instrumen

$i_{0} \quad$ : skor paling rendah yaitu 1

$N$ : jumlah penelis

$C$ : skor pilihan yang tertinggi yaitu 5

Hasil uji panelis tes pengetahun dasar matematika dari 20 butir soal diperoleh semua $V_{i}>0,60$ maka butir tersebut valid. Sementara itu, Hasil uji panelis tes hasil bealjar matematika dari 20 butir soal diperoleh semua $V_{i}>0,60$ maka butir tersebut valid. Untuk menghitung tingkat keterandalan dari butir soal tersebut dipakai rumus Alpha Cronbach, yaitusebagai berikut.

$$
r_{i t}=\left(\frac{n}{n-1}\right)\left(1-\frac{\sum s_{i}^{2}}{s_{t}^{2}}\right)
$$

$$
\begin{aligned}
& \text { Keterangan: } \\
& \mathrm{n} \quad=\text { Banyaknya item } \\
& s_{i}{ }^{2}=\text { Jumlah varians skor tiap } \\
& s_{t}{ }^{2}=\text { Varians skor total } \\
& \quad \text { Interpretasi nillai uji reliabilitas }
\end{aligned}
$$
disajikan dalam tabel 2.

\begin{tabular}{ll}
\multicolumn{2}{l}{ Tabel 2. Interpretasi Reliabilitas } \\
\hline Besarnya nilai $\boldsymbol{r}$ & Interpretasi \\
\hline$r_{i t} \leq 0,20$ & Sangat rendah \\
$0,20<r_{i t} \leq 0,40$ & Rendah \\
$0,40<r_{i t} \leq 0,70$ & Sedang \\
$0,70<r_{i t} \leq 0,90$ & Tinggi \\
$0,90<r_{i t} \leq 1,00$ & Sangat tinggi \\
\hline
\end{tabular}

Jihad dan Haris (2012: 180) mengemukakan bahwa reliabilitas instrumen reliabel jika $r_{i t}>0,40$ dan tidak reliabel jika $r_{i t}<0,40$. Hasil analisis reliabilitas instrumen tes hasil belajar matematika dengan menggunakan alat bantu SPSS diperoleh koefisien reliabilitasnya sebesar 0,716 yang dapat diinterpretasikan dalam kategori tinggi. Jadi, dapat disimpulkan bahwa instrumen tes pada penelitian ini ada 20 soal yang valid dan reliabel, sehingga instrumen tersebut layak digunakan untuk mengukur hasil belajar matematika siswa kelas $\mathrm{X}$ SMA Negeri 1 Lawa pada materi fungsi.

Teknik pengumpulan data dalam penelitian ini menggunakan metode tes. Tes pada penelitian ini menggunakan tes soal pilihan ganda yang akan digunakan untuk memperoleh data tentang pengetahuan dasar matematika dan hasil belajar matematika. Skor perolehan siswa kemudian dikonversi ke skala 100 dengan aturan:

$$
\text { Nilai }=\frac{\text { skor perole han siswa }}{\text { skor mak simal }} \times 100
$$

Analisis data dalam penelitian ini dilakukan dengan menggunakan dua jenis analisis, yaitu analisis deskriptif dan analisis inferensial. Analisis deskriptif diperlukan untuk mendeskripsikan atau menggambarkan karakteristik distribusi masing-masing data variabel pengetahuan dasar matematika dan hasil belajar matematika.

Rujukan kriteria untuk nilai pengetahuan dasar matematika dan hasil belajar matematika berdasarkan Panduaan Penilaian oleh Pendidik dan Satuan Pendidikan untuk Sekolah Menengah Atas oleh Kementerian Pendidikan dan Kebudayaan tahun 2017 siswa dapat dlihat pada tabel 3 . 
Tabel 3. Rujukan Nilai Pengetahuan Dasar Matematika dan Hasil Belajar Matematika Siswa Kelas X SMA Negeri 1 Lawa untuk KKM 68

\begin{tabular}{ll}
\hline Interval Predikat & Kategori \\
\hline $89<X \leq 100$ & Sangat Baik \\
$79<X \leq 89$ & Baik \\
$68<X \leq 79$ & Cukup \\
$X \leq 68$ & Kurang \\
\hline
\end{tabular}

Tahap selanjutnya dalam analisis data adalah analisis inferensial. Dalam analisis inferensial, terdapat beberapa tahap analisis yang menjadi prasyarat untuk melakukan analisis uji hipotesis yaitu analisis uji normalitas data dan analisis uji linearitas data dan dilanjutkan dengan uji hipotesis menggunakan uji korelasi linear sederhana dan analisis regresi linear sederhana.

Pada tahap awal dilakukan pengujian untuk mengetahui hubungan atau korelasi pengetahuan dasar matematika dengan hasil belajar matematika. Untuk mentukan nilai korelasi dapat dilakukan dengan menggunakan rumus korelasi product moment berikut.

$$
r_{X Y}=\frac{N \sum X Y-\left(\sum X\right)\left(\sum Y\right)}{\sqrt{\left\{N \sum X^{2}-\left(\sum X\right)^{2}\right)\left\{N \sum Y^{2}-\left(\sum Y\right)^{2}\right\}}}
$$

Keterangan :

$r_{X Y}$ : Koefisien korelasi antara variabel $\mathrm{X}$ dan variabel Y

$\mathrm{N}$ : jumlah responden

$X$ : variabel bebas

$Y$ : variabel terikat

Jihad dan Haris (2013: 180), mengungkapkan interpretasi terhadap nilai koefisien korelasi dapat dilihat pada tabel 4.

\begin{tabular}{ll} 
Tabel 4. Interpretasi Nilai Koefisien Korelasi \\
\hline Besarnya nilai $\mathbf{r}$ & Interpretasi \\
\hline $0,800<\mathrm{r}_{\mathrm{xy}} \leq \mathbf{1 , 0 0}$ & Sangat tinggi \\
$0,600<\mathrm{r}_{\mathrm{xy}} \leq \mathbf{0 , 8 0 0}$ & Tinggi \\
$0,400<\mathrm{r}_{\mathrm{xy}} \leq \mathbf{0 , 6 0 0}$ & Cukup \\
$0,200<\mathrm{r}_{\mathrm{xy}} \leq \mathbf{0 , 4 0 0}$ & Rendah \\
$0,00<\mathrm{r}_{\mathrm{xy}} \leq \mathbf{0 , 2 0 0}$ & Sangat rendah \\
\hline
\end{tabular}

Pengujian hipotesis dalam regresi linear sederhana digunakan statistik uji $\mathrm{t}$ yang diperoleh dengan rumus berikut.

$$
t=\frac{r \sqrt{n-2}}{\sqrt{1-r^{2}}}
$$

Kriteria uji: $\quad$ Jika , $-\mathrm{t}_{\text {tabel }} \leq \mathrm{t}_{\text {hitung }} \leq \mathrm{t}_{\text {tabel, }}$ maka $\mathrm{H}_{0}$ diterima dan Jika , $\mathrm{t}_{\text {hitung }}>\mathrm{t}_{\text {tabel, }}$ maka $\mathrm{H}_{0}$ ditolak

\section{HASIL PENELITIAN}

Hasil analisis deskriptif terhadap gambaran tentang karakteristik responden (siswa) dari masing-masing variabel penelitian yaitu pengetahuan dasar
Untuk mengetahui seberapa pengaruh yang diberikan oleh pengetahuan dasar matematika terhadap hasil belajar matematika siswa kelas X SMA Negeri 1 Lawa digunakan koefisien determinasi dengan menggunakan alat bantu SPSS. 
Tabel 5 Analisis Deskriptif Pengetahuan Dasar Matematika dan Hasil Belajar Matematika Siswa Kelas X SMA Negeri 1 Lawa

\begin{tabular}{lll}
\hline & $\mathbf{X}$ & $\mathbf{Y}$ \\
\hline $\mathrm{N}$ & 67 & 67 \\
Rata-rata & 69,85 & 71,72 \\
Median & 70,00 & 75,00 \\
Modus & 65 & 75 \\
Std. Deviasi & 15,496 & 13,832 \\
Varians & 240,129 & 191,327 \\
Minimum & 40 & 45 \\
Maksimum & 95 & 95 \\
\hline
\end{tabular}

Nilai Pengetahuan dasar matematika diperoleh dari tes pengetahuan dasar matematika yang diberikan secara langsung oleh peneliti yang dianalisis secara manual kemudian dikelompokkan yang diperoleh kategori seperti pada tabel 6.

Tabel 6 Interval Nilai masing-masing kategori untuk variabel $X$

\begin{tabular}{clcc}
\hline Interval Predikat & Kategori & Frekuensi & Persentase(\%) \\
\hline $89<\mathrm{Y} \leq 100$ & Sangat baik & 10 & 14,9 \\
$79<\mathrm{Y} \leq 89$ & Baik & 12 & 17,9 \\
$68<\mathrm{Y} \leq 79$ & Cukup & 14 & 20,9 \\
$68<\mathrm{Y} \leq 79$ & Kurang & 31 & 46,3 \\
\hline Jumlah & & 67 & 100 \\
\hline
\end{tabular}

Berdasarkan tabel 6 distribusi frekuensi pengetahuan dasar matematika siswa kelas X semester genap SMA negeri 1 Lawa menunjukan bahwa dari 67 siswa kelas $\mathrm{X}$, siswa yang hasil pengetahuan dasar matematika sangat baik sebanyak 10 siswa (14,9\%), siswa yang hasil pengetahuan dasar matematika baik sebanyak 12 siswa (17,9\%), siswa yang hasil pengetahuan dasar matematika cukup sebanyak 14 siswa (20,9\%), dan siswa yang hasil pengetahuan dasar matematika kurang sebanyak 31 siswa $(46,3 \%)$.
Berdasarkan hal ini dapat dikatakan bahwa secara keseluruhan dari perolehan nilai siswa untuk tes pengetahuan dasar matematika yang dilakukan tergolong kategori kurang karena memiliki persentase terbesar dibanding dengan kategori-kategori lainnya.

Nilai hasil belajar matematika diperoleh dari tes matematika yang diberikan secara langsung oleh peneliti tersaji pada tabel 7.

Tabel 7 Interval Nilai masing-masing kategori untuk variabel $Y$

\begin{tabular}{clcc}
\hline Interval Predikat & Kategori & Frekuensi & Persentase(\%) \\
\hline $89<\mathrm{Y} \leq 100$ & Sangat baik & 10 & 14,9 \\
$79<\mathrm{Y} \leq 89$ & Baik & 12 & 17,9 \\
$68<\mathrm{Y} \leq 79$ & Cukup & 19 & 28,4 \\
$68<\mathrm{Y} \leq 79$ & Kurang & 26 & 38,3 \\
Jumlah & & 67 & 100 \\
\hline
\end{tabular}


Berdasarkan tabel 7 distribusi frekuensi hasil belajar matematika siswa kelas $\mathrm{X}$ semester genap SMA Negeri 1 lawa menunjukan bahwa dari 67 siswa kelas $\mathrm{X}$, siswa yang hasil belajarnya sangat baik sebanyak 10 siswa (14,9\%), siswa yang hasil belajarnya baik sebanyak 12 siswa $(17,9 \%)$, siswa yang hasil belajarnya cukup sebanyak 19 siswa $(28,4 \%)$, dan siswa yang hasil belajarnya kurang sebanyak 26 siswa $(38,8 \%)$.

Hasil analisis untuk pemeriksaan terhadap kenormalan data untuk variabel $\mathrm{X}$ dan Y dilakukan dengan uji KolmogrovSmirnov dengan bantuan SPSS. Hasil perhitungannya disajikan dalam tabel 8 .

Tabel 8. Hasil Analisis Statistik Uji Normalitas Data untuk Variabel X dan Variabel Y Melalui Uji Kolmogorov Smirnov

\begin{tabular}{llll}
\hline & & $\mathbf{X}$ & $\mathbf{Y}$ \\
\hline $\mathrm{N}$ & & 67 & 67 \\
Normal parameter $^{\mathrm{a}}$ & Rata-rata & 69,85 & 71,72 \\
& Std.Deviasi & 15,496 & 13,832 \\
Perbedaan & Absolut & 0,105 & 0,116 \\
Kebanyakan & Positif & 0,086 & 0,078 \\
Ekstrem & Negatif & $-0,105$ & $-0,116$ \\
Kolmogorov-smirnov Z & 0,856 & 0,951 \\
\multicolumn{2}{l}{ Asimp.Sig (2-arah) } & 0,457 & 0,326 \\
\hline
\end{tabular}

a. distribution tes adalah normal.

Berdasarkan tabel 8 dapat dilihat bahwa nilai signifikansi lebih besar dari nilai $\alpha(0,457>0,05)$. Dengan demikian dapat disimpulkan bahwa data pengetahuan dasar matematika berdistribusi normal. Selanjutnya, uji normalitas dengan menggunakan uji Kolmogrov-Smirnov untuk variabel Y diperoleh nilai signifikansi lebih besar dari nilai $\alpha(0,326>0,05)$. Dengan demikian dapat disimpulkan bahwa data hasil belajar matematika berdistribusi normal.

Hasil analisis untuk pemeriksaan kelinearan data variabel $\mathrm{X}$ terhadap $\mathrm{Y}$ dilakukan dengan bantuan SPSS. Hasil perhitungannya disajikan dalam tabel 9.

Tabel 9. Hasil Analisis Statistik Uji Linearitas Data Variabel X terhadap Variabel Y

\begin{tabular}{|c|c|c|c|c|c|c|c|}
\hline & & & $\begin{array}{l}\text { Jumlah } \\
\text { Kuadrat }\end{array}$ & df & $\begin{array}{l}\text { Kuadrat } \\
\text { Rata-rata }\end{array}$ & $\mathbf{F}$ & Sig. \\
\hline \multirow{5}{*}{$\mathrm{Y}^{*} \mathrm{X}$} & Antara & (kombinasi) & 8195,112 & 11 & 745,010 & 9,244 & 0,000 \\
\hline & Grup & Linearitas & 7833,408 & 1 & 7833,408 & 97,200 & 0,000 \\
\hline & & $\begin{array}{l}\text { Penyimpangan } \\
\text { dari Linearitas }\end{array}$ & 361,704 & 10 & 36,170 & 0,449 & 0,915 \\
\hline & $\begin{array}{l}\text { Dalam } \\
\text { grup }\end{array}$ & 4432,500 & 4432,500 & 55 & 80,591 & & \\
\hline & Total & 12627,612 & 12627,612 & 66 & & & \\
\hline
\end{tabular}

Berdasarkan tabel 9 dapat dilihat bahwa $\mathrm{H}_{0}$ diterima atau dengan kata lain data variabel $\mathrm{X}$ dan variabel $\mathrm{Y}$ memiliki hubungan yang linear.
Hasil analisis untuk pemeriksaan korelasi antara variabel $\mathrm{X}$ terhadap $\mathrm{Y}$ dilakukan dengan bantuan SPSS. Hasil perhitungannya disajikan dalam tabel 10 . 
Tabel 10 Hasil Uji Korelasi variabel X dan Y

\begin{tabular}{llll}
\hline & & X & Y \\
\hline X & Pearson korelasi & 1 & $0,788^{* *}$ \\
& Sig. (2-arah) & & 0,000 \\
& N & 67 & 67 \\
Y & Pearson korelasi & $0,788^{* * *}$ & 1 \\
& Sig. (2-arah) & 0,000 & \\
\multicolumn{1}{l}{ N } & 67 & 67 \\
**. Korelasi signifikan pada tingkat 0,01 (2-arah).
\end{tabular}

Hasil analisis pada tabel 10 diperoleh nilai koefisien korelasi antara pengetahuan dasar matematika dan hasil belajar matematika sebesar 0,788. Nilai koefisien korelasi adalah positif, sehingga korelasi atau hubungan antara pengetahuan dasar matematika dengan hasil belajar matematika searah. Selain itu, dari hasil analisis tabel 10 diperoleh nilai Asymp. Sig. (2-tailed) sebesar 0,000 dengan $\alpha=0,05$. Karena $0,000<0,05$ maka $H_{0}$ ditolak dan disimpulkan bahwa pengetahuan dasar matematika mempunyai korelasi positif yang signifikan dengan hasil belajar matematika siswa kelas X SMA Negeri 1 Lawa.

Pengujian terhadap pengaruh pengetahuan dasar matematika terhadap hasil belajar matematika siswa kelas $\mathrm{X}$ SMA Negeri 1 Lawa digunakan regresi linear sederhana. Pengujian hipotesis ini menggunakan program aplikasi SPSS. tertera pada tabel 11 .

Tabel 11. Koefisien Regresi

\begin{tabular}{lllllll}
\hline Model & \multicolumn{1}{c}{$\begin{array}{c}\text { Bukan standar } \\
\text { Koefisien } \\
\text { Std. Eror }\end{array}$} & $\begin{array}{c}\text { Standar } \\
\text { koefisien } \\
\text { Beta }\end{array}$ & t & Sig. \\
\hline 1 (konstan) & 22,608 & 4,879 & & 4,634 & 0,000 \\
$\mathrm{X}$ & 0,703 & 0,068 & 0,788 & 10,306 & 0,000 \\
\hline
\end{tabular}

a.Variabel terikat: $\mathrm{Y}$

Hasil analisis uji regresi tabel 11 diperoleh nilai konstan sebesar 22,608 dan nilai koefisien penegtahuan dasar matematika sebesar 703. Hal ini dapat dibuat fungsi taksiran regresinya adalah $\hat{Y}$ $=22,608+0,703 x$. Ini berarti bahwa kenaikan variabel pengetahuan dasar matematika meningkat 1 satuan, maka nilai hasil belajar akan meningkat sebesar 0,703 satuan dengan nilai konstanta 22,608. Selain itu, diperoleh nilai Asymp. Sig. (2-tailed) sebesar 0,000 dengan $\alpha=$ 0,05 . Karena $0,000<0,05$ maka $\mathrm{H}_{0}$ ditolak yang berarti bahwa pengetahuan dasar matematika mempunyai pengaruh positif yang signifikan terhadap hasil belajar matematika siswa kelas X SMA Negeri 1 lawa.

Selanjutnya untuk mengetahui seberapa besar pengaruh yang diberikan oleh pengetahuan dasar matematika terhadap hasil belajar matematika siswa kelas X SMA negeri 1 Lawa digunakan koefisien determinasi dengan menggunakan alat bantu SPSS. Berikut tabel koefisisen determinasi yang tertera pada tabel 12 . 
Tabel 12. Hasil Koefisien Determinasi Variabel X Terhadap Y

\begin{tabular}{|c|c|c|c|c|}
\hline Model & $\overline{\mathbf{R}}$ & R kuadrat & $\begin{array}{c}\text { R kuadrat } \\
\text { disesuaikan }\end{array}$ & $\begin{array}{c}\text { Standar perkiraan } \\
\text { kesalahan }\end{array}$ \\
\hline 1 & $0,788^{\mathrm{a}}$ & 0,620 & 0,614 & 8,588 \\
\hline
\end{tabular}

Dari tabel 12 diperoleh bahwa besarnya pengaruh variabel pengetahuan dasar matematika terhadap hasil belajar matematika siswa kelas X SMA Negeri 1 Lawa dapat diketahui melalui besarnya koefisien determinasi $\left(r^{2}\right)$ yaitu 0,620.

\section{PEMBAHASAN}

Konsep-konsep matematika tersusun secara hierarkis, konsep yang satu menjadi dasar untuk mempelajari konsep selanjutnya. Sifat ini menyebabkan penguasaan matematika siswa pada proses pembelajaran dipengaruhi oleh kemampuannya menguasai konsep matematika sebelumnya. Hal ini mengakibatkan pengetahuan dasar matematika siswa sangat bergantung pada penguasaan konsep dasar matematika yang telah mereka peroleh di jenjang Sekolah dasar.

Pengetahuan dasar matematika keseluruhan siswa kelas X SMA Negeri 1 Lawa secara keseluruhan dari perolehan nilai siswa untuk tes pengetahuan dasar matematika yang dilakukan tergolong kategori kurang karena memiliki persentase terbesar dibanding dengan kategori-kategori lainnya.

Hasil belajar matematika siswa kelas $\mathrm{X}$ semester genap SMA Negeri 1 Lawa menunjukan bahwa secara keseluruhan dari perolehan nilai siswa untuk tes hasil belajar matematika yang dilakukan tergolong kategori kurang karena memiliki persentase terbesar dibanding dengan kategori-kategori lainnya.

Hasil uji linearitas antara pengetahuan dasar matematika dan hasil belajar matematika siswa kelas X SMA Negeri 1 Lawa untuk sampel memiliki
Dengan demikian besarnya kontribusi pengetahuan dasar matematika terhadap hasil belajar matematika siswa adalah 62,0 $\%$ dan sisanya $38,0 \%$ dipengaruhi oleh faktor lain.

hubungan yang linear menunjukan bahwa pengetahuan dasar matematika dan hasil belajar matematika siswa berbanding lurus. Artinya semakin tinggi pengetahuan dasar matematika siswa maka hasil belajar yang diperoleh semakin baik, sebaliknya jika pengetahuan dasar matematika yang diperoleh siswa rendah makan hasil belajarnya akan rendah.

Hasil pengujian korelasi menggunakan korelasi product moment (pearson), diperoleh bahwa pengetahuan dasar matematika mempunyai korelasi positif yang signifikan dengan hasil belajar matematika siswa. Artinya, jika semakin tinggi pengetahuan dasar matematika siswa, maka hasil belajar matematika akan semakin tinggi. Sebaliknya, jika semakin rendah pengetahuan dasar matematika siswa, maka hasil belajar matematika akan semakin rendah.

Fungsi taksiran regresinya adalah $\hat{Y}=22,608+0,703 x$ menunjukkan bahwa kenaikan variabel pengetahuan dasar matematika meningkat 1 satuan, maka nilai hasil belajar akan meningkat sebesar 0,703 satuan dengan nilai konstanta 22,608 . Secara statistik pengetahuan dasar matematika mempunyai pengaruh positif yang signifikan terhadap hasil belajar matematika siswa kelas X SMA Negeri 1 Lawa. 
Pada uji statistik pengaruh, menggunakan analisis regresi sederhana diperoleh nilai koefisien determinasi sebesar $62,0 \%$, ini berarti bahwa $62,0 \%$ sumbangan yang terjadi pada hasil belajar matematika siswa dipengaruhi oleh pengetahuan dasar matematika siswa, selebihnya 38,0\% dipengaruhi oleh faktor lainnya yang tidak diteliti dalam penelitian ini.

Penelitian ini berhasil menemukan bahwa pengetahuan dasar matematika berpengaruh positif terhadap hasil belajar matematika siswa. Bentuk pengaruh pengetahuan dasar matematika dengan hasil belajar matematika adalah pengaruh positif yang ditunjukkan dengan nilai-nilai regresi yang bertanda positif. Hal ini dapat dilihat pada persamaan regresi $\hat{Y}=22,608$

\section{KESIMPULAN DAN SARAN}

Berdasarkan hasil penelitian dan pembahasan, maka diperoleh beberapa kesimpulan sebagai berikut.

1. Analisis deskriptif kelas X SMA Negeri 1 Lawa sebanyak 67 siswa pada variabel pengetahuan dasar matematika diperoleh nilai rata-rata 69,85 (kategori cukup). Nilai maksimum 95 dan nilai minimum 40 dengan standar deviasi 15,496. Sedangkan variabel hasil belajar matematika nilai rata-rata sebesar 71,72 (kriteria cukup). Nilai maksimum 95 dan nilai minimum 45 dengan standar deviasi 13,832.

2. Pengetahuan dasar matematika mempunyai pengaruh positif yang signifikan terhadap hasi belajar matematika siswa kelas X SMA Negeri

\section{DAFTAR PUSTAKA}

Arbain. 2011. Pengaruh Motivasi Berprestasi dan Pengetahuan Dasar terhadap hasil Belajar matematika SMA. Jurnal Pendidikan Matematika.
$+0,703 x$ Dari fungsi tafsiran regresi tersebut terlihat bahwa nilai konstanta 22,608 merupakan nilai hasil belajar matematika siswa tanpa ditunjang oleh pengetahuan dasar matematika. Sedangkan koefisien arah regresi $x$ sebesar 0,703 menunjukkan pengetahuan dasar matematika berpengaruh positif terhadap hasil belajar matematika. Dengan demikian, dapat dijelaskan bahwa jika variabel pengetahuan dasar matematika meningkat, maka akan diikuti dengan meningkatnya hasil belajar matematika siswa. Demikian sebaliknya, jika variabel pengetahuan dasar matematika menurun, maka akan diikuti dengan menurunnya hasil belajar matematika siswa.

1 Lawa, yang ditunjukan dengan $\hat{Y}=$ $22,608+0,703 x$, dengan koefisien determinasi yaitu 0,620 atau $62,0 \%$.

Berdasarkan pembahasan dan kesimpulan hasil penelitian, dapat disarankan seabagai berikut.

1. Siswa hendaknya menguasai konsep dasar matematika supaya dapat meningkatkan hasil belajar matematikanya.

2. Bagi guru SMA Negeri 1 Lawa khususnya pada kelas $\mathrm{X}$ agar selalu meningkatkan pengetahuan dasar matematika yang ada kaitannya dengan pembelajaran yang sedang berlangsung.

Hudojo, H. 2003. Pengembangan Kurikulum dan Pembelajaran Matematika. Surabaya : Usaha Nasional. 
Jihad, A. dan Abdul Haris. 2013. Evaluasi Pembelajaran. Yogyakarta: Multi Perindo.

Maonde, F. 2016. Pengaruh Minat Terhadap Hasil Belajar Matematika Melalui Kombinasi Model Pembelajaran Kooperatif. Jurnal Pendidikan Matematika.

Ruseffendi, E. T. 1993. Pendidikan Matematika 3. Jakarta: Universitas Terbuka.

Sardin. 2005. Pengaruh Penguasaan Konsep Dasar Matematika Terhadap Prestasi Belajar Matematika Siswa Kelas 1 SMA Negeri 1 Wundulako. Skripsi. FKIP, UHO: Kendari

Slameto. 2015 .Belajar dan Faktor-faktor yang mempengaruhinya. Jakarta: Rineka Cipta. 